\title{
HISTORY OF COMPUTING IN EDUCATION An Overview
}

\author{
John A.N. Lee \\ Virginia Tech and Radford University, USA \\ E-mail: janlee17@verizon.net
}

\begin{abstract}
This paper provides an overview of the history of computing and its affect on computing in education. It describes the evolution of the history of computing through activities such as conferences, collection and archival activities, individual collections, books and journals, and websites. It also illustrates the use of computers in the history of education in areas such as computing education, engineering, home and office, and the classroom. The paper brings light the importance of history in fulfilling the legacy of different areas of learning.
\end{abstract}

Key words: History of computing; Computing education; History; Education; Organizations; Museums; Virtual museums

\section{INTRODUCTION}

From the early general accessibility of the computer, there was a need for training in the methods of programming computers. The primary focus was on the retraining of mathematicians and engineers, as they were thought to have natural abilities to use calculators. Computers were simply extensions of the calculator medium. Interested parties of the time did not anticipate that computers would be much more than special calculators that had the ability to complete solutions to bigger problems in less time. Thus, computer education in the 1950 s centered primarily on numerical methods and the ability to express solutions in the new language of computers. For many users, this was a fairly logical extension of the instructions that had been laid out for human computers to follow-those (generally female) workers who spent their days doing calculations to solve problems using tabular instruction sets prescribed by researchers or engineers. The use of 
computers in education developed initially as an extension of the general (commonly repetitive) problem solving exercises. For those of who were in college in the 1950s, they should recall that students became accustomed to the drudgery of solving daily problem exercise sets. The intent was to ensure that students understood the material they learned that day. Computer programming followed a different approach, akin to learning a topic by teaching it. If students could express the means for solving a problem by designing a program, then it meant that they also understood how to solve the problem themselves. To achieve this goal, it was also necessary to teach students the syntax of computer programming, whereas the ability to use of slide rules and calculators was assumed.

Perhaps as late as the mid-1960s, computers in education had not spread much wider than engineering, mathematics, and the emerging field of computer science. Then, the non-numeric use of computers started to grow and the availability of "personal computing" through time-sharing systems gave birth to the ideas of "computer aided instruction". While there were pockets of excellence in this field, CAI did not reach most locations until the advent of the world wide web.

The topic of this conference is the history of computing in education, with the expectation that we can review and document the impact of the computer on education. One portion of this documentation is the development of courses on the history of computing and the use of history as a tool in education.

\section{HISTORY OF THE HISTORY OF COMPUTING}

Many timelines and chronologies describe well the history of computing. Most sources are available through the world wide web. However, the history of the development of the field of the history of computing is less well known. One of the drawbacks has been the lack of recognition of the history of computing field as being appropriate at this stage of the development of the computer. Most historical studies view their field from a viewpoint of at least one hundred years, whereas computing is just about sixty years old and the most recent innovations that affect our daily lives are less than thirty years old. However, there were pioneers who decided that it was important to preserve the history of computing while both their colleagues and their artifacts were still around. 


\subsection{The Stages of Historical Preservation}

History provides a reporting system that allows us to look back at our developments over the years and to use history to guide future progress. Computer history is lucky in one aspect that it is so recent that many of our pioneers still live and we have the opportunity to preserve their artifacts and documents. Computer history is unlucky in another aspect in that it is so recent that most professional historians disregard it and do not provide the impetus either to preserve our history or to apply their well-established techniques of analysis and scrutiny. Thus, the field of the history of computing has primarily been the domain of amateurs. Much of the preservation of computer history has been the hobby of enthusiasts who were not prepared to accept the tenet of the Virginia Department of Historic Resources that nothing after 1865 , the date of the end of the American Civil War, is history!

\subsubsection{Conferences}

The 1973 Los Alamos Conference on the History of Computing in the Twentieth Century organized by Nick Metropolis was perhaps the earliest significant step in the preservation of the history of computing. The meeting brought together a large number of computer pioneers. Richard Hamming best expressed the theme of the meeting in his keynote presentation where he suggested that the reason for the gathering was "that we would know what they thought when they did it" [Metropolis et al, 1980]. While the proceedings were not available until seven years after the conference, the impetus it provided was momentous.

The first conference on the History of Programming Languages, organized in 1978 by Jean Sammet and J.A.N. Lee, was a direct consequence of the Los Alamos conference and the first organized by a professional society [Wexelblat, 1981]. It was the first of what most hoped to be a series of meetings in the style "The History of ..." organized by the Association for Computing Machinery, bringing together pioneers from specific fields. This 1978 meeting was important for bringing out a number of significant revelations, not the least of which was the announcement by Capt. Grace Murray Hopper of the preservation of the first computer bug. Later conferences included the histories of included the History of Medical Informatics, and the History of Personal Workstations, as well as a second History of Programming Languages conference in 1993 [Bergin, et al, 1996].

In 1976, the American Federation of Information Processing Societies (AFIPS) initiated Pioneer Days at the behest of Jean Sammet, the chair of 
the AFIPS History of Computing Committee (HOCC). In association with the National Computer Conferences they included the following areas[Sammet, 1985]:

1974 Dartmouth Time-sharing System

1975 Institute for Advanced Study and the IAS Computer

1976 ENIAC

1977 Los Alamos Scientific Laboratory

1978 Standards Western Automatic Computer (SWAC)

1979 COBOL

1980 The Founding of SHARE

1981 UNIVAC

1982 The Stored Program Concept and the $25^{\text {th }}$ Anniversary of FORTRAN

1983 Howard Aiken and the Harvard Computation Laboratory

1984 Lawrence Livermore National Laboratory

1985 The First Illinois Computers

On 31 December 1990, AFIPS dissolved, and while constituent societies had taken over some of the other elements of the organization, Pioneer Days were not. Upon the founding of IFIP Working Group 9.7 in 1992, Pioneer Days was to become an integral part of IFIP World Computer Congresses. The concept received the enthusiastic support of Gesellschaft fur Informatik (GI) in Hamburg in 1994, led by Klaus Brunnstein. Intended for the host country to recognize and publicize their contributions to the history of computing, WCC Pioneer Days have taken place in 1994 (Germany), 1996 (Australia), 1998 (Austria/Hungary), and 2000 (China).

Perhaps the longest continuum of national history conferences was the French Colloque sur l'Histoire de l'Informatique soon to have its seventh meeting (ESAT, Cesson-Rennes, 16-18 November 2004). These meetings were primarily the child of Pierre Mounier-Kuhn (CNAM). More recently, John Impagliazzo, current chair of IFIP Working Group 9.7, has organized meetings and a conference on the History of Nordic Computing in 2003 June. He is encouraging other conferences in Europe and elsewhere.

\subsubsection{Collection and Archival Activities}

The Museum of History and Technology (now the National Museum of American History) of the Smithsonian Institute had been accepting bits and pieces of computer history when in 1970 AFIPS approached them with a proposition, written by Walter Carlson to initiate an oral history project. Hank Tropp of Humboldt State University became the curator for this project and conducted over 250 oral interviews by the time they dissolved the project in 1973. Unfortunately, many these interviews are still not 
publicly available. However, the Smithsonian moved forward with a project to develop a public exhibit that opened in 1990 called the "Information Age". This exhibit wisely contains dual tracks of communications and computers that eventual merge in the display. With constant updates, this exhibit is still very popular.

In the late 1970s Gwen and Gordon Bell convinced the Digital Equipment Corporation to establish a small display of devices in the foyer of the plant in Marlborough, Massachusetts. Their displays soon exceeded the available space. Hence, with DEC funding, they moved to establish the Computer Museum in Boston where it had many successful years. Whilst their collections and displays were magnificent, one of the greatest initiatives was the annual "Computer Bowl" that was not only a great fund raising venture, but also a fantastic learning opportunity shared by many college students. In 1996 the collections were moved to the West Coast and now became the initial elements of the Computer History Museum in Mountain View, California. Established in 1996, the Computing History Museum is a public benefit organization dedicated to the preservation and celebration of computing history. It is home to one of the largest collections of computing artifacts in the world, a collection comprising over 4,000 artifacts, 10,000 images, 4,000 linear feet of cataloged documentation and gigabytes of software [CHM www].

The Science Museum, London, includes a Computing and Information Technology collection that is perhaps most famous (today) for the reconstruction of the Babbage Difference Engine No. 2. Computing and Information Technology covers the devices, machines and systems from 1623 (first mechanical calculator) to the present. Its scope includes electromechanical and electronic calculation, analog and digital computation, data management and processing, and cryptography [SML www].

Also in the UK, the Computer Museum at Bletchley Park claims to be the UK's only hands-on exhibition of computing hardware and software technology. It traces the development of the computer from its origins with the Colossus, invented during the Second World War to break Lorenz codes through the mainframes of the 1960s, mini computers, homebuilt micros to the PC's of today. The vast majority of our exhibits are operational [CMB WWw].

The Heinz Nixdorf Museums Forum in Paderborn, Germany HNF, claims to be the largest computer museum in the world, and is also an important conference center. The exhibition rooms begin on the first floor charting the development of the cultural technologies of calculating, writing, and drawing up through the invention of the first computer. The second floor builds on the first-floor displays through the representation of the 
development, dissemination, and application of electronic data processing. The last fifty years of the development of information and communications technology unfold in this room and convey a sense of the ever-increasing pace of technological innovation [HNM www].

A number of companies have established their own museums, primarily to display their own products or use of their products. The Intel Museum is located in Santa Clara, California, and features a new exhibit highlighting 35 years of Intel corporate history and innovation. Several smaller semi-public computer museums also exist (or used to exist) in California, particularly the ones established by Apple Computer, Hewlett-Packard Corporation, IBM, Intel Corporation, and the Lawrence Livermore National Laboratories. Some museums are still in operation, some are in suspended animation, and some are just plain gone-meaning, paradoxically, that computers, or other artifacts from their own collections, may be in danger. While many museums have worked hard at fulfilling their stated purposes, none of them has ever aspired to the global treatment of California's computing [CHAC www].

Several university-based collections including the University of Amsterdam, the American University (Washington DC), and others also exist. For example, Professor Gabriel Robins conceived and created the University of Virginia's Computer Museum; Robins also serves as its curator. The museum contains various computer-related artifacts, both historical and modern. Most of the artifacts shown there are physically located in display cases in the hallways of the Department of Computer Science (Olsson Hall) at the University of Virginia.

As another example, a coalition of Stanford computer scientists has installed exhibits within the Gates Computer Science building containing historical equipment and documents focusing on Stanford's role in the history of computing. The exhibits change and become updated as time permits. The first exhibit, installed November 1997, focuses on the early history of the Stanford Computer Science Department, its founder George Forsythe, and his students [Stanford www].

The Charles Babbage Institute is an historical archives and research center of the University of Minnesota. CBI is dedicated to promoting study of the history of information technology and information processing and their impact on society. CBI preserves relevant historical documentation in all media, conducts and fosters research in history and archival methods, offers graduate fellowships, and sponsors symposia, conferences, and publications. The archival collection consists of corporate records, manuscript materials, records of professional associations, oral history interviews, trade publications, periodicals, obsolete manuals and product literature, photographs, films, videos, and reference materials. CBI also 
serves as a clearinghouse for resources on the history of information technology [CBI www].

\subsubsection{Private Collections}

The American Computer Museum, Bozeman, Montana, opened in 1990 as a U.S. non-profit corporation. Originally, the developers planned the museum to be in Princeton, New Jersey, but after looking at the tourism in the area the founders moved it to Bozeman. Located in beautiful Montana, the museum draws thousands of visitors from all fifty states and over fifty countries. With Yellowstone National Park to the south and Glacier National Park to the northwest, the museum is part of sightseeing itineraries by visitors worldwide. From its inception, the American Computer Museum has emphasized the evolution of the information age with an emphasis on the United States. Nevertheless, there are ample displays throughout the museum that highlight the contributions made by other nations and cultures to the rise of the information age. The American Computer Museum has been written about in many publications including, The New York Times, The New Yorker Magazine, The Los Angeles Times, PC Week, QST Magazine, and USA Today (ACMB www).

The DigiBarn Computer Museum seeks to capture personal stories and track technological evolution through a large collection of vintage computer systems, manuals, videos, interviews, and other fossil relics of the "Cambrian explosion" of personal computing that ignited in 1975. The organizers claim that "When we get visitors who 'burst into tears' upon seeing certain systems which may have defined their lives and careers, our cameras roll to capture the inevitable stories. Thus, the interconnected redwood rooms of the museum constitute a kind of "memory palace" for the nerd-inclined and help us piece together the amazing story of the invention of personal computing and Cyberspace." [DBCM www] The DigiBarn is a ninety plus years old barn constructed of old growth redwood that is part of the original "Ancient Oaks Ranch", a 19th century farmstead nestled deep in the Santa Cruz Mountains of Northern California.

\subsubsection{Books and Journals}

Like computing itself, the history of computing has taken a set of brave publishers to have the faith in sales and marketing to justify the printing of books appropriate to school and college courses. Regrettably, publishers do not often reprint these books and many excellent texts are no longer available. However, the collection is growing steadily, though the interest in more recent history far outweighs the longer views. The field has the 
support of only one journal, the IEEE Annals of the History of Computing, published since 1978; it is a superior source of materials. Recently the IEEE Computer Society has digitized the issues back to 1978 and made them available through their digital library. Occasionally, articles appear in other professional journals, but frequently they have not had the review and editing that is necessary to check the validity of the information.

The same is true of textbooks targeted to the beginning computing courses, and many myths of computing continue to promulgate through the lack of qualified reviewers. The references to this paper document many of the available books and other resources.

\subsubsection{Web Sites}

American University Computing History Museum and its website originated in 1999 to support the historiography of programming languages and software engineering [AUCHM www]. Supported by a multi-year grant from the Alfred E. Sloan Foundation, the original site was part of the HotNet Project, which provided funding to universities to create web sites to support the historiography of various technologies.

The Virtual Museum of Computing [VMC www] includes an eclectic collection of world wide web hyperlinks connected with the history of computing and online computer-based exhibits available both locally and around the world. This museum opened on 1 June 1995 and has expanded to cover many non-computer specific museums. The site includes an extremely useful set of links to many other museums.

Smaller virtual museums include many university collections such as the Computer Museum at the University of Queensland [CMQ www], which primarily contains a collection of documents and images tracing the development of computers and their associated peripherals from the early 1960s, when they installed a General Electric Model GE225 as the first digital computer at the University and in Queensland. As a source of certain "old" documents, this may be very useful to students

\section{COMPUTERS IN THE HISTORY OF EDUCATION}

\subsubsection{Computing Education}

Howard Aiken at Harvard University was probably the first to offer computer courses. His courses centered primarily on numerical applications with programming and the computer was more of a calculation tool along 
with the calculator and slide rule. In the early 1960s, computer science programs began to appear in US universities, though frequently the field appeared as a sub-discipline of mathematics or engineering in many institutions. As a service discipline, they commonly taught programming to those who had applications, and research in computing was concentrated on hardware and numeric applications. It was not until the late 1960s that they followed pursuits that were more theoretical and even later they began to view software engineering as vogue.

\subsubsection{Computers in Engineering}

Engineers have always had the difficulty of finding the means to do computation based on problem solving for the analysis and design of their products. Thus, engineers were among the first to recognize the usefulness of computers and, typical of their approach to other needs, frequently chose to be the teachers of their own students. Even as ardent users of computer engineers were not forward in using computers in education.

\subsubsection{Computers in the Office}

In the office, computers were slow in acceptance, though the advent of time-sharing and the emergence of text editing systems such as IBM SCRIPT accelerated the infusion in the late 1970s. Like many other fields, the introduction of the personal computer provided a large impetus to have computers replace typewriters and consequently, it raised the need for training for office staff. Distinct from general education, training for office staff did not include instruction in the fundamentals and concepts of the field. Thus, much of office training dealt with computer-based systems. The success of these systems has led to their being available to students in schools and colleges so that they could attain skill levels that depend more on demonstration and exercise than on understanding and comprehension.

\subsubsection{Computers in the Classroom}

Computer Aided Instruction (CAI) has been a long time goal of the computer area, originating probably in the early 1960s. However, it did not really become practical until the introduction of the world wide web. In the early days perhaps the most effective CAI systems were the business games that simulated various industries, the most common being the "widget" business that allowed students to simulate their involvement in various aspects of a manufacturing and marketing company. Commonly used in summer schools for students in business schools or for executives in MBA- 
style programs, one could play them over long periods and integrate the games into the general curriculum. These still exist in the form of the "SIM" products and in other invocations.

The PLATO system, started back in 1960, became a technological solution to deliver individualized instruction in thousands of subjects from algebra to zoology to students in schools and universities across the nation. As the system grew and evolved, it became, pretty much by accident, the first major online community, in the current sense of the term. In the early 1970s, people lucky enough to have exposure to the system discovered that it offered a radically new way of understanding the use of computers; computers were not just about number-crunching (and delivering individualized instruction). They were about people connecting with people. For many PLATO people who came across PLATO in the 1970s, this was a mind-blowing concept.

The PLATO system finds its origins in the early 1960s at the University of Illinois at Urbana. Don Bitzer, its developer, was an electrical engineering professor who had an interest in using computers for teaching. Together with several colleagues, they founded the Computer-based Education Research Laboratory (CERL). The original PLATO system was comprised of custom developed hardware and software and was one of the first time-sharing systems. In 1972, they ported the software to a more powerful mainframe platform with support for hundreds of simultaneous users. As the Control Data Corporation ran into financial trouble in the late 1980s and microcomputers became a more cost-effective platform than mainframes, many PLATO systems closed down. The PLATO name was sold to a Minneapolis-based company called PLATO Learning, Inc. Control Data's PLATO system was renamed CYBIS, and continued to be supported at several university and government sites still running the original PLATO Notes software. The University of Illinois PLATO system was renamed NovaNET, and transferred to a private company called NovaNET Learning, Inc., of Tucson, Arizona [Nova www].

With the advent of the world wide web, new teaching/testing systems developed that provided a myriad of customized services that supported a computer aided teaching/learning environment. For example, Blackboard offers a complete suite of enterprise software products and services that power e-education programs in primary markets such as pre-college, college, university, corporate/government, and international education programs. Blackboard solutions deliver the promise of the internet for online teaching and learning, campus communities, campus commerce services, and integration of web-enabled student services and back office systems [Blackboard www]. 
WebCT claims to be the leading provider of e-learning solutions for higher education. It began as an educator's dream to provide students with a flexible, integrated environment where teachers could use the latest technology to foster inquiry, encourage discourse, and inspire collaboration. Today, its mission is to help institutions deliver on their commitment to educational excellence with enterprise-wide learning management solutions that integrate the richest and most flexible pedagogical tools with existing campus infrastructure [WebCT www].

Students studying calculus, linear algebra, and other mathematics subjects at Virginia Tech have been engaged in exciting new ways to learn through the Math Emporium [MathEmp www]. Established in 1997 in a disused department store site, the Emporium contains 500 machines arranged in pods of five systems. Each pod is dedicated to a specific course topic and allows students to share experiences as they undertake their learning and practice. The emporium developed on faculty members' years of experience as teachers. It also used their years of increasing experience with computer technology and course innovations for which the mathematics department and individual faculty members have won numerous awards. From the outset, students know the learning goals of a course plus important learning milestones they must meet. They set their own schedules. They learn at their own pace. They receive immediate feedback on quizzes and problems. They explore alternative approaches to learning challenging material. They interact one-on-one with faculty and other students. They master coursework as well as -- and often better -- than in conventional classrooms.

The Math Emporium is a facility with 500 high-performance dualplatform computers arranged in state-of-the-art workstations. Customized, easy-to-use computer programs guide students through their coursework, allowing them to breeze through material they quickly master and to concentrate their time on more challenging concepts. In addition, students can work individually or in groups of up to eight students, giving all students the opportunity to create the best match between their learning environment and their own learning style. Students also have the opportunity to work one-on-one with professors and with graduate and undergraduate student coaches as much or as little as they need. Studies have shown that students using technology in mathematics courses typically outperform their peers in traditional classroom settings. However, because it is new and experimental, professors are studying and assessing Math Emporium activities closely to find out what works well and what elements of it they can improve. Faculty members individually monitor students' progress through their course work to ensure that no one falls behind. Students' comments and concerns receive top priority in creating or refining coursework and computer software. 
Another form of CAI tool is the simulators that are commonly used in military systems or flight training. While most such simulators primarily intend to provide a hands-on experience, there is a growing trend to the use of simulators in the classroom to understand better concepts and fundamentals of complex systems. As the complexity and variety of computer system hardware increases, its suitability as a pedagogical tool in computer organization/architecture courses diminishes. Consequently, many instructors are turning to simulators as teaching aids. They often use valuable teaching/research time to construct them. Many of these simulators are freely available on the Internet, providing a useful and timesaving resource for other instructors. However, finding the right simulator for a particular course or topic can itself be a time-consuming process [Wolffe, 2002]. Beyond computer science, simulators are useful in role-playing environments, gaming, and business simulations [Krauss, 1999]. Using SimCity and Sim 2000 from Electronic Arts, students learn to build simulated cities and get hands-on experience meeting the challenges presented in city administration such as zoning, taxing, budgeting, power, transportation, pollution, crime, and land value.

\subsubsection{Computers in the Home}

As in the office, computers came into the home with the advent of the personal computer. Driven primarily by young people, the computer in the home has become almost as pervasive as the telephone and the television. An August 2003 survey by the Pew Internet Project [Pew, 2003] reported on the following results.

- $63 \%$ of Americans now go online. That amounts to $47 \%$ growth in the U.S. adult population using the internet, from 86 million in March 2000 to 126 million in August 2003.

- $52 \%$ of internet users go online on a typical day, as of August 2003. That figure amounts to 66 million people and has grown from 52 million who were online during a typical day in March 2000.

- $87 \%$ of U.S. internet users said they have access at home, and $48 \%$ said they have access at work.

- $25 \%$ said they use the internet at times from some place other than home or work in a March-May 2003 survey.

- $31 \%$ of internet users who go online from home have broadband access.

With numerous school systems in the U.S. now providing computers to their students, the extension of the school into the home for out-of-school assignments has extended the use of computers in education in the home. 


\section{SUMMARY}

The history of computing in educations has many facets. From the early days, people viewed computers as sophisticated number crunchers and as extensions of calculators. Hence, computer education in the 1950 s consisted of numerical methods for solving mathematical and scientific problems. After the mid-1960s, non-numeric use of computers started to grow. Once "personal computing" became available and time-sharing systems became pervasive, new ideas began to emerge. This gave birth to "computer aided instruction", perhaps the historical hallmark of the dynamic use of computers in an educational environment.

It should be clear that from historical beginnings to the uses of computing today, teachers at all levels should be mindful of the emergence of computing in the courses they teach, its place in the curriculum, and its function in the full educational program of their students. One way of doing this is to include vignettes of computing history in the courses they teach. For example, in a music class, could have students the history of the use of computers in the music composition. The discovery of the Moog Synthesizer may fascinate budding students and perhaps encourage them to seek further ways in which they could use computers in music development. The same is true for other areas of learning. Computing history can add new dimensions to existing courses by connecting modern technology to the subject at hand.

Professional organizations should also be mindful of roots of computing in their respective areas. For example, it would be useful to see know how computers first affected the areas such as accounting, architecture, and medicine. Unfortunately, the historical aspects professional activity is not a priority and often ignored. Even in computing, one would think that the preservation of its own beginnings and evolution should meaningful. Alas, only few organizations address this dimension of the computing field. Fortunately, some do. For example, the IEEE Computer Society, while not primarily a history organization, has been a leading light in the recognition of computer pioneers by initiating the Computer Pioneer Award in 1980. The recipients have included many well-known persons as well as some who were much more in the background but truly worthy of recognition. While other computing organizations worldwide have recognized pioneers in their field, such recognition has not become a priority in the work that they do. Perhaps in time, other societies will recognize the need for being historically proactive and present a stimulus for its members and associates.

In summary, the history of computing is important to learning in all fields of education, especially in computing education. The hope is that this 
message will stimulate interest in young and veteran scholars and provide a legacy for future generations.

\section{ACKNOWLEDGEMENTS}

The author is grateful for the invitation of conference to present this invited paper, and of the encouragement and support of John Impaglizzo, Peter Bollerslev, and Jan Wibe to create this overview as both my "swan song" and my version of Captain Hook's last speech!

\section{REFERENCES}

ACMB, 2004, American Computer Museum, Bozeman, Montana. http://www.compustory.com/american_computer_museum.htm, undated, last accessed 14 April 2004.

AUCHM, 2004, American University Computing History Museum. http://www.computinghistory museum.org/, undated, last accessed 14 April 2004.

Aspray, William, 1990, Computing Before Computers. Iowa State University Press, 1990.

Babbage, Charles. 1961, On the Principles and Development of the Calculator and Other Seminal Writings by Charles Babbage and Others. Dover Publications, 1961.

Bashe, Charles J., Lyle R. Johnson, John H. Palmer, and Emerson W. Pugh, 1968, IBM's Early Computers. Cambridge, Mass.: MIT Press

Baum, Claude, 1981, The System Builders: The Story of SDC. Santa Monica, CA: System Development Corporation.

Bergin, Thomas J., Gibson, Richard (eds), 1996, History Of Programming Languages. Reading, Mass.: Addison-Wesley.

Blackboard, undated, http://www.blackboard.com/about/index.htm

Campbell-Kelly, Martin and William Aspray, 1996, Computer: A History of the Information Machine. New York, NY: Basic Books.

Campbell-Kelly, Martin, Mary Croarken, Raymond Flood, Eleanor Robson, 2003, The History of Mathematical Tables: From Sumer to Spreadsheets. Oxford, UK: Oxford University Press.

Campbell-Kelly, Martin, 2003, From Airline Reservations to Sonic the Hedgehog: A History of the Software Industry. Cambridge, MA.: MIT Press.

CBI, Charles Babbage Institute, 2004, http://www.cbi.umn.edu/about/mission.html, undated, last accessed 14 April 2004.

Ceruzzi, Paul E., 1998, A History of Modern Computing. Cambridge, MA: The MIT Press.

Ceruzzi, Paul, E., 1983, Reckoners: The Prehistory of the Digital Computer, from Relays to the Stored Program Concept, 1935-1945. Westport.CT: Greenwood Press.

Chapuis, Robert J. and Amos E. Joel, Jr., 1990, Electronics, Computers and Telephone Switching, Part III. Amsterdam, New York, Oxford: North-Holland Publishing Company.

CMQ, 2004, Computer Museum at the University of Queensland. http://www.computer.museum .uq.edu.au/, undated, last accessed 14 April 2004.

Cohen, I. Bernard, and Gregory W. Welch, 1999, Makin' Numbers: Howard Aiken and the Computer. Cambridge, MA: The MIT Press. 
Cohen, I. Bernard, 1999, Howard Aiken: Portrait of a Computer Pioneer. Cambridge, MA: The MIT Press.

CHAC, 2004, Computer History Association of California, http://www.chac.org/chintro.html, undated, last accessed 14 April 2004.

CHM, 2004, Computer History Museum, http://www.computerhistory.org/about/index.page, undated, last accessed 14 April 2004.

CMB, 2004, Computer Museum at Bletchley Park. http://www.retrobeep.com/, undated, last accessed 14 April 2004.

DeLamarter, Richard Thomas, 1986, Big Blue: IBM's Use and Abuse of Power, New York: Dodd, Mead.

DBCM, 2004, DigiBarn Computer Museum, http://www.digibarn.com/about.html, undated, last accessed 14 April 2004.

Englebourg, Saul, 1976, International Business Machines: A Business History. New York: Arno Press. Orig. pub. as a Ph.D. thesis, Columbia University, 1954.

Fisher, Franklin, M., James W. McKie, and Richard B. Mancke, 1983, IBM and the U. S. Data Processing Industry: An Economic History. New York: Praeger.

Fishman, Katherine Davis, 1981, The Computer Establishment. New York: Harper \& Row.

Forman, Richard L., 1985, Fulfilling the Computer's Promise: The History of Informatics, 1962-1968. Woodland Hills, California.: Informatics

Freiberger, Paul and Michael Swaine, 2000, Fire in the Valley: The Making of the Personal Computer, second edition. New York, NY: McGraw-Hill.

Hall, Eldon C., 1996, Journey to the Moon: The History of the Apollo Guidance Computer. American Institute of Aeronautics and Astronautics.

HNM, undated, Heinz Nixdorf Museums Forum. http://hnf.paderborn.museum/

Hodges, Andrew, 1983, Alan Turing: The Enigma. New York, NY: Simon \& Schuster.

Ifrah, George, 1999, The Universal History of Numbers: From Prehistory to the Invention of the Computer. New York: John Wiley \& Sons.

Ifrah, George, 2001, The Universal History of Computing: From the Abacus to the Quantum Computer. New York, NY: John Wiley \& Sons.

Imlay, John P., Jr. with Dennis Hamilton, 1994, Jungle Rules: How to be a Tiger in Business. New York, NY: Dutton.

Kestin, Hesh, 1992, 21st Century Management: The Revolutionary Strategies that Have Made Computer Associates a Multi-Billion Dollar Software Giant. New York, NY: The Atlantic Monthly Press.

Krauss, Michael, 1999, Simulating Real World Environments, http://www.lclark.edu/ krauss /tesol98/sim.html

Kurtzig, Sandra L. with Tom Parker, 1991, CEO: Building a \$400 Million Dollar Company from the Ground Up. New York, NY: W. W. Norton \& Company.

Lammers, Susan, 1986, Programmers at Work: Interviews with 19 Programmers Who Shaped the Computer Industry. Washington, D.C.: Tempus, Redmond.

Lee, John A.N, 1995, Computer Pioneers. Los Alamitos CA: IEEE Computer Society Press.

Levering, Robert, Michael Katz, and Milton Moskowitz, 1984, The Computer Entrepreneurs. New York: New American Library.

Levy, Steven, 1984, Hackers: Heroes of the Computer Revolution. Norwell, MA: Anchor Press.

Manes, Stephen and Paul Andrews, 1993, Gates: How Microsoft's Mogul Reinvented an Industry — and Made Himself the Richest Man in America. New York, NY: Doubleday. 
MathEmp, Math Emporium, 2004,

http://www.emporium.vt.edu/emporium/newVisitor/index.html, undated, last accessed 14 April 2004.

Maurice V. Wilkes, 1995, Memoirs of a Computer Pioneer. Cambridge, MA: MIT Press.

McCartney, Scott, 1999, ENIAC: The Triumphs and Tragedies of the World's First Computer. New York, NY: Walker Publishing.

Metropolis, Nicholas, J. Howlett, and Gian-Carlo Rota, eds., 1980, A History of Computing in the Twentieth Century, New York: Academic Press.

Nova, 2004, NovaNET Learning. http://livinginternet.com/r/ri_talk.htm, undated, last accessed 14 April 2004.

Nyce, James M. and Paul Kahn, 1991, From Memex to Hypertext: Vannevar Bush and the Mind's Machine. New York, NY: Academic Press.

Pew Internet Project, December 22, 2003, America's Online Pursuits: The changing picture of who's online and what they do. http://www.pewinternet.org/reports/toc.asp?Report=106

Phister Jr., Montgomery. 1979. Data Processing: Technology and Economics. Santa Monica, Calif.: Digital Press and Santa Monica Publishing Co.

Pugh, Emerson W., 1995, Building IBM: Shaping an Industry and Its Technology. Cambridge, MA: MIT Press.

Riordan, Michael and Lillian Hoddeson, 1997, Crystal Fire: The Birth of the Information Age. New York, NY: W.W. Norton \& Company.

Rojas, Rual, Ulf Hashagen (eds), 2002, The First Computers-History and Architectures. Cambridge, MA: MIT Press.

Sammet, Jean E., 1969, Programming Languages: History and Fundamentals. Englewood Cliffs, N.J.: Prentice-Hall.

Sammet, Jean E., 1985, Answers to Self-Study Questions. Annals of the History of Computing, Vol. 7, No. 4, p. 361.

SML, 2004, Science Museum London. http://www.sciencemuseum.org.uk/collections /subject_themes/computing.asp, undated, last accessed 14 April 2004.

Sobel, Robert, 1981, IBM: Colossus in Transition. New York: Times Books.

Stanford, undated, Stanford University, Gates Computer Science Building. http://wwwdb.stanford.edu /pub/voy/museum.html

U. S. Department of Commerce, 1984, A Competitive Assessment of the United States Software Industry. Washington, D.C.: U.S. Department of Commerce.

VMC, 2004, Virtual Museum of Computing, http://vmoc.museophile.org, undated, last accessed 14 April 2004.

WebCT, 2004, http://www.webct.com /company, undated, last accessed 14 April 2004.

Wexelblat, R. L., 1981, History of Programming Languages. New York, London: Academic Press.

Williams, M.R., 1997, A History of Computing Technology, Second Edition. Los Alamitos CA: IEEE Computer Society Press.

Wolffe, Gregory S., William Yurcik, Hugh Osborne, and Mark A. Holliday, 2002, Teaching computer organization/architecture with limited resources using simulators. Proceedings of the 33rd SIGCSE Technical Symposium on Computer Science Education, Cincinnati, Kentucky,pp. 176-180 